\title{
Whitehead: Mundos em processo - Parte 1
}

Fernando Silva e Silva e Bárbara de Barros Fonseca

\section{Apresentação}

Alfred North Whitehead nasceu em Ramsgate, na Inglaterra, em 1861 e morreu em 1947 em Cambridge, nos Estados Unidos. Foi um matemático e filósofo de algum renome em vida, mas, pouco tempo após sua morte, caiu em quase total esquecimento, com a exceção de alguns poucos pesquisadores estadunidenses e franceses que mantiveram em curso um debate em torno de sua obra e de suas ideias.

As razões para tal esquecimento não são fáceis de delimitar, mas podemos levantar algumas suposições. Primeiramente, Whitehead não se preocupou em criar uma escola de pensamento ou preparar sucessores; seu interesse estava acima de tudo no crescente refinamento científico e filosófico de sua proposta teórica. Em segundo lugar, o filósofo não possui um lugar adequado na divisão entre "analíticos" e "continentais" que marcou o pensamento do século XX, dependendo da obra ou do conceito em questão, ele poderia ser classificado em uma ou outra categoria, ou nas duas, ou em nenhuma. Em terceiro lugar, a sua crescente ênfase em problemas de cosmologia e metafísica a partir dos anos 1920 vai totalmente na contramão do que se fazia e faria tanto em filosofia "analítica" quanto “continental", assim como em outras áreas do conhecimento; o pensamento whiteheadiano é inimigo declarado dos materialismos substancialistas e dos mentalismos idealistas ou linguísticos que dominaram o século XX.

Nas últimas décadas, no entanto, tem havido um resgate das obras de Whitehead, com novas edições e traduções ao redor do mundo. No mundo anglófono, é impossível ignorar o trabalho contínuo da Process Network, que já realizou 12 edições da International Whitehead Conference desde 1981; no debate francófono, Bruno Latour e Isabelle Stengers tiveram o importante papel de, desde o final dos anos 1970, não só retomar a filosofia whiteheadiana, mas também levá-la para outras áreas do conhecimento e para a divulgação científica. No Brasil, e na comunidade lusófona em geral, o debate em torno do pensamento whiteheadiano está apenas começando. Aqui, apenas algumas obras de Whitehead estão traduzidas e a maioria delas está esgotada. Em Portugal, a tradução de Processo e Realidade, considerada a principal obra do autor, ainda não completou uma década. No Brasil, não há nem mesmo previsão de sua tradução. 
Em um momento histórico em que estamos reavaliando as relações globais de poder na produção de conhecimento, qual o interesse para um país do Sul em conhecer mais um autor que encarna todas as características do sujeito majoritário: branco, europeu, heterossexual e cristão? O cerne da reflexão de Whitehead está na crítica dirigida às categorias fundamentais da ciência e da filosofia modernas, sobretudo ao conceito de natureza, e suas sustentações físicas e metafísicas, e à separação entre sujeito e objeto. Seu pensamento é extremamente pertinente em um momento histórico em que precisamos re-elaborar as relações entre humanos, entre humanos e não-humanos e entre humanos e a Terra. Sua metafísica especulativa se desafia a incluir todos os modos de existência, todas as perspectivas, buscando afirmar o valor intrínseco de cada entidade atual, reconhecer sua importância, em vistas de uma civilização que possibilite não só viver, mas viver bem.

Esta edição especial da revista Das Questões, dedicada à obra e ao pensamento de Alfred North Whitehead e àquilo que ele nos inspira, será publicada em duas partes, devido ao volume de textos que recebemos. A realização da 12th International Whitehead Conference na Universidade de Brasília em agosto de 2019 criou um ambiente de discussão em torno de Whitehead até então inexistente em nosso país. No entanto, será possível notar que a maior parte das contribuições, em especial nesta primeira parte, é de autores estrangeiros. Que esta edição especial da revista Das Questões contribua para o avanço e multiplicação das pesquisas no Brasil sobre Whitehead.

Esta primeira parte conta com 5 artigos inéditos, resultantes de apresentações na 12 th International Whitehead Conference: Creativity, fragility, and concern, de Ulysse Gadiou; Teaching and learning STEM disciplines, de Roland Cazalis; Canalization and creative evolution, de Tano Posteraro; Apetições atadas em feixes: Whitehead e o campo da arte, de Vinícius Portella; e Whitehead's French readers, de Fernando Silva e Silva. Além disso, contamos também com a tradução - realizada por Fernando Silva e Silva - de $O$ universo perspectivista: Natureza e subjetividade na metafísica contemporânea, de Didier Debaise. Até onde pudemos verificar, se trata do primeiro texto deste filósofo belga traduzido no Brasil. Esses seis textos formam uma gama diversa de entradas na obra do autor, encontramos análises de tipo conceitual, estético, historiográfico, comparativo e aplicado, representando o grande impulso criativo sugerido pela obra whiteheadiana. 